\title{
The Increase in Porang Instant Noodle Market Share from the Perspective of Transformative Business Model Analysis
}

\author{
Novrizal $^{1}$, Florentina Rahayu ${ }^{1}$, Joni Phangestu ${ }^{2}$, Nora S. Hendriyeni ${ }^{2}$ \\ ${ }^{1}$ PPM School Management, Gedung Bina Manajemen, Jl. Menteng Raya No.9, RT.1/RW.10, Kb. Sirih, Kec. \\ Menteng, Kota Jakarta Pusat, Daerah Khusus Ibukota Jakarta 10340 \\ ${ }^{2}$ Lecturer of Management at PPM School Management, Gedung Bina Manajemen, Jl. Menteng Raya No.9, \\ RT.1/RW.10, Kb. Sirih, Kec. Menteng, Kota Jakarta Pusat, Daerah Khusus Ibukota Jakarta 10340
}

Corresponding Author: Novrizal

\begin{abstract}
Indonesia is one of the 10 countries with the consumption of the world's biggest instant noodles. One alternative to raw materials that instant noodles are healthier than iles-iles porang or bulbs. Through connecting consumer needs with developing technology that is Transformative Business Model, this research aims to: 1) Learn how the companies condition instant noodles made from porang (porang instant noodles) currently; 2) Figure out the model business to run the porang instant noodles company; 3) Identify the challenges in porang instant noodles industry; 4) Recommend the increase in market share of porang instant noodles. Conceptual framework in this research processed through PESTEL analysis, Porter's Five Forces Model analysis, Competitive Profile Matrix (CPM), Value Chain analysis. The conceptual framework validated by Transformative Business Model. The results showed that the challenges are not coming from competitors, but comes from the main raw material suppliers up to now only have one company. One company subdue the raw material market supply also makes high dependency in industry. On the other hand, potential market share in porang instant noodles is still huge to local as well as the international market.
\end{abstract}

Keywords: market share, consumer needs, technology, instant noodle, Porang,

Transformative business model.

\section{INTRODUCTION}

Indonesia is one of 10 countries with the biggest level of consumption of instant noodles in the world. Based on data from World Instant Noodles Association (WINA), in 2020, made Indonesia in second place after China /Hong Kong, with a level of consumption of 12,6 billion packs of instant noodles in a year. From the data, an average Indonesian million population of 270 consume 1 pack of instant noodles. Every week the high consumption of instant noodles in Indonesia because of factors including low prices and easy access to buy instant noodles. Besides, instant noodles and readily served in cook. As well as having a unique and interesting flavor.

Actually, Indonesia has great potential in terms of basic food besides rice and food alternative of instant noodles. One that is popular now is instant noodles from a healthy iles-iles or porang tuber. A tuber of porang owning amount minimizes glucomannan which high and carbohydrate content and almost no calories. Supriati, 2016 explained the glucomannan is used to lower blood glucose, prevent cancer, impeded sent down obesity, and address constipation. The benefits of instant noodles made from porang be one alternative that is suitable for consumption staple food of most to those who already knows the ropes the importance of maintaining health. 
Environmental conditions business and industries in the world run faster, especially technology development and information. It cannot be denied that these two factors would be the main factor in the business to make a difference. Technology cannot stand alone to change an industry. Some industries have done previous research to find how to transform business models in a business firm. By connecting the customer needs with technology, develop as a transformative business model (Kavadias, Ladas, and Loch, 2016). Transformative business model research was 40 model to the business of various industries, from hospitality, banking, transportation, electronic business operator to taxi distinguished in the world. Transformative business models to market needs (consumers) with technology that developing innovation is key to success (key success of innovation). This study looks at the process; useful started in innovation to transformation in a business. Transformative research business model concluded, there are 6 a key innovation success covering; personalization, a close loop, assets sharing, used based pricing, collaborative ecosystem, and agility.

Information from above, the author felt the need went further related instant noodle industry-based porang to see factors what to speed up the development of the 6 concerning the success of innovation. This underlying of researchers to conduct research called the increase in market share through instant noodles is based porang transformative business model.

\section{LITERATURE REVIEW PESTEL Analysis}

An outer external environment in its scope affected how a company walk and do business called macro with the environment. A macro-environment consists of the factors sourced from beyond the one company that may present opportunities or threaten a strike against the company. On the other hand, the company did not directly affect the macro environment. In the face of a macro environment, the company can anticipate the impact that could be caused by the macro environment (Cadle, Paul, and Turner, 2010).

\section{Porter's Five Forces Model Analysis}

The external environmental analysis was done by adopting the method of analysis industry from Michael Porter. Analysis Porter's Five Forces Model Analysis is an apparatus that simple but useful to understand where the underlying corporate strength us in dealing with the situation in the world of business competition (Cadle, Paul, and Turner, 2010). Through an analysis of five of these forces, we can understand the power of competition in the country and the power of the position on the business competition that is going forward.

\section{Competitive Profile Matrix}

Competitive Profile Matrix (CPM) is an external environmental analysis to compare companies and all their competition. As well as expressing, power weakness is owned by companies and main competitor company in a particular industry based on critical success factor and company strategy (Bhattacharjee and Dey, 2015). Ovidijus Jurevicius (2013) to steer the CPM area to know which areas should be improved and which areas to be covered.

\section{Customer Behaviour}

According to Schiffman, Kanuk, and Hansen (2012), Consumer behavior is a process traversed by someone searching for, buying, using, evaluating. It will be after consumption of the product and services, and ideas are expected to fulfill their needs. And from the perspective of Engel, Blackwell, and Miniard (2001), consumer behavior is a product of the acts of services, including the process directly in a obtain, consume and also a will disposing of a product or service, including the process of a decision that will precede and follow this course of action. 


\section{Value Chain Analysis}

Porter's Value Chain focusing on a system and how input is converted into an output that the consumer buys. Use this point of view; porter describes chain activities common to all business.

\section{Transformative Business Model}

There are six key success factors related to the trend in the long term in the transformation; the business model is to see the development of technology and the market. The technology describes how technology can be apparatus for developing and connecting a business intelligence through technology-based internet, the data, artificial intelligence, to decode it largescale data storage safe, how an enterprise embodies a business idea to be real with more efficient and effective so that what is needed by the market is much easier, cheap, and higher accuracy to his success measurable. Technology also allows businesses to do defense scale in deciding the CPO output until the distribution is done on a small scale.

\section{METHODS}

The kind of data was used in the study, primary and secondary data. The primary data represents data obtained through in-depth interviews with informants. The primary data and data are taken directly from the source without intermediate to researchers (Muhtar dan E Widodo, 2000:117). The primary data used as their main source of research to answer questions and decision-making to the research question. The primary data represents data who deliberately collected to assist it to carry about problems in the analysis is as high as. The primary data in this research was obtained by conducting interviewing management firm engaged in industrial porang. Data processing interview on research is that the interview data reduction transcript aims to collect data and filter content relevant to research and analysis aimed at measuring and analyzing, existence meaning, said, relationship, theme or a concept of particular relevance to a research.

\section{RESULTS \\ Macro Analysis}

Macro analysis in this research will use PESTEL analysis to deepen the macro situation. To complete the analysis of the global situation more influenced by the technology and digital technology trend analysis.

The external outermost environment is the macro environment. The macroenvironment can affect the firm's environment, whether in the form of positive opportunities and negative in the form of threats to the sustainability of a business firm. The company did not have the power to change the factors that were sourced from beyond the companies. The macro-environment analysis used is political analysis, economic, social \& culture, technology, and environment (PESTEL).

The decline in civil liberties in a landscape of Indonesian politics is a less current weakening of the role of civil society and declines in appreciation of political rights and civil liberties in Indonesia. Based on the annual global, freedom house the monitoring and supporting democracy established in 1941, in New York Indonesia index declining political rights and civil society in significant freedom in the last few years since 2014-2020. (Kompas.com)

Indonesian economy contraction of the growth as the year 2020 experienced $2.07 \%$ consumer to consumer (C2C) compared to 2019 (BPS, 2021). The country's economic growth is positive following its growth forecast 2021 Indonesia of over level 4,5-5,5 percent. Economic growth this year is still dependent on the development of covid-19 and the process of vaccination. If the transmission can be reduced and vaccination successfully, then the implications for economies positive. (analisis.kontan.co.id 2021). 
Pandemics Covid-19 in Indonesia since March a historical momentum measures that must be taken, force us to 33 countries to adapt to whatever new stand or new normal. Pandemic is a crisis of global and can be a momentum for the huge transformation, such as a very play an important role in various aspects of the community life. The technology used in schools uses face-to-face online using the internet as a means of teaching and learning. The same thing happened to micro and small entrepreneurs who position technology application as the main support to keep the economy remains walk and growing, although 33 countries not over yet. Pandemics covid-19 is an event that disruption routine us so that to endure, we have to build a new culture, including new tradition new discipline. In this era of new normal deserves consideration is building the structure knowledge and awareness.

The most promising technological innovation in the industrial sector food was smart manufacturing, allowing automation of food production. The procurement of the technology allows automation for each food off the production lines, ranging from processing raw materials to packing. With this technology, firms operating in food production can make efficient in the production process, which is a repetition. Thus, human resources in the company can perform other duties more complicated. The speed of the production can be measured with precision because the whole process of doing consistent with a machine (Sumber: Talenta. co). Climate change has a terrible effect on Indonesia, especially in the security sector, food, and fisheries sector.

The drought that occurred in Indonesia, planting patterns also changes during the rainy season when flooding resulting in crops failing. Besides, climate change has shifted the ocean currents and causes acidifying marine to cause the declining fish catch.

Legislation of number 11 of the year 2020 about Cipta Kerja (UU Ciptaker One of them related to government regulation
(PP) Number 28 of the year 2021 On the industry's implementation. This regulation can support the acceleration of the industrial sector in the country and spur its development to compete globally with sacred printing. This will provide facilities and business certainty for industries.

Based on the survey held byWorld Economic Forum (Future of Jobs Survey 2018), four techniques will dominate in the year 2018-2022, namely are high-speed mobile internet, artificial intelligence, big data analytics, dan cloud technology. Fourth is believed to be technology will greatly influence the development of all of the company business. For the year 2022, $92 \%$ of companies in Indonesia will adopt big data analytics as one of the main technology. This was also the case; the proportion of large enough would happen to the use of technology another at the industrial revolution 4.0, like the internet of things, machine learning, and cloud computing.

\section{Industry Analysis}

Industry analysis using analysis Porter's 5 Forces Model is to know whether the instant noodles are based porang an industry that attracts or less attractive. Industry analysis was also carried out using a competitive profile matrix to capture critical success and the strategy for the company. With analysis is also expected to be known in the industry.

The newcomers, porang in the industry with the resulting aids of instant noodles are based porang, is still low; this is the main supplier of the raw material used to make instant noodles from flour porang difficult. In Indonesia, there has just been PT. Ambico a single supplier capable of producing shirataki noodles with the export. To cooperate, get a supply of a basic source of some instant noodles from PT. Ambico must go through the fit and proper test that each supplier determines; the process is not the fit and proper test implicit. The decision to cooperate or does not still have the right to collect suppliers. 
Based on the functions and benefits of food products, substitutes against the threat of instant noodles made from porang each has a relatively low. Only three companies producing instant noodles are based on porang, a retail market, so the choice to consume instant noodles is based on porang limited with three brands: Fitmee, Ashitaki. The latest is Tropicana Slim Shirataki Noodles.

The price is the main issue for the people of Indonesia, especially when we see the Indonesian people purchasing power is still low. Price instant noodles made porang with basic price range Rp19.900 - 20.700 . According to the issued by World Bank 2020, people to the middle class are the group most large in the population of Indonesia.

Product availability of instant noodles is based on porang is not spread equally across the country. Penetration done by each of the enterprises related distribution is still different. The availability of these instant noodles products is still dominated by retail largest online in a whole variety of Indonesia markets.

The bargaining power of suppliers is quite high, while there are only companies that become suppliers, and it can be said is the sole supplier of a basic source of some instant noodles made from porang is PT. Ambico Indonesia. The competition among competitors of the instant noodles made from porang classified as low. The lack of competition because the instant noodles are based companies, porang new there namely Fit Indonesia Tama Company (Fitmee), and PT Aquasolve Sanaria (Ashitaki), and in the March year 2021, PT Nutrifood Indonesia introducing products made of porang, namely Tropicana Slim Shirataki Noodles.

\section{Competitive Profile Matrix (CPM)}

PT. Fit Indonesia Tama Is one of a subsidiary Fit Indonesia Tama Company. The companies running the business use science too, business expansion strengthens the concept wellness ecosystem, includes distributors onto the fitness bar, exercise place for fitness, restaurant, producer healthy food. PT. Fit Indonesia Tama continues to conduct product marketing to innovation and development, one of which is through the marketplace. The market that exists can link all lines of business Fit Indonesia Tama Company. Innovation is done by integrating a line of business PT Fit Indonesia Tama on providing information related to training schedule catering, lunch menu ordering dinner, seek personal trainer, etc.

PT. Aquasolve Sanaria manufactures food products healthy and quality, as shirataki noodles, creamy drink latte, and cake premix. All products sold by PT Aquasolve Sanaria Containing low on calories, low sugar, free cholesterol and high antioxidant that fits perfectly healthy easily to diet. The company added to the ashitaki material called ashitaba, having the anti an oxidant good for the body as added value and judgment of similar products.

Tropicana Slim Shirataki Noodles is the product diversification the newest of the Tropicana Slim Under big names of PT. Nutrifood Indonesia So this is really focused on develops and markets products which have characteristics health. Instant noodles Tropicana slim shirataki had only just come on in the stage explore the market, yet in but was officially launching test tokopedia and e-commerce market by online shop website Nutrimart.co.id. These products have the same raw materials produced by dry shirataki noodles on PT. Ambico Indonesia at Jawa Timur. To scratch prime test the market is there is one variant taste that is fried noodles special.

\begin{tabular}{|l|l|l|l|}
\hline Factor & Fitmee & Ashitaki & Tropicana Slim \\
\hline $\begin{array}{l}\text { Promotion } \\
\text { Media }\end{array}$ & $\begin{array}{l}\text { Focus on social media as } \\
\text { Instagram and Facebook with } \\
\text { a view to more benefit and } \\
\text { socialize }\end{array}$ & $\begin{array}{l}\text { YouTube ) } \\
\text { there are key opinion leader ( KOL ) } \\
\text { promo cooperation with modern retail market }\end{array}$ & $\begin{array}{l}\text { nutrimart.co.id ( new test } \\
\text { markets march 2021 ) } \\
\text { social media tropicana slim }\end{array}$ \\
\hline
\end{tabular}


Novrizal et.al. The increase in porang instant noodle market share from the perspective of transformative business model analysis.

\begin{tabular}{|c|c|c|c|}
\hline \multicolumn{4}{|c|}{ Table 1 Continued... } \\
\hline $\begin{array}{l}\text { Innovation } \\
\text { Process }\end{array}$ & $\begin{array}{l}\text { on the orientation of, variant is } \\
4 \text { the current sense and would } \\
\text { soon melaunching one a new } \\
\text { variant }\end{array}$ & $\begin{array}{l}\text { focus on packaging and variant of another of noodles } \\
\text { was } 7 \text { variant and would soon } 3 \text { variant and launching a } \\
\text { new sense of innovation on seasoning with adding the } \\
\text { ashitaba has the an oxidant significantly better for the } \\
\text { body }\end{array}$ & N/A \\
\hline Market Share & $\begin{array}{l}\text { The milenial - (age } 25-35) \text { to } \\
\text { healthy living in } 10 \text { major } \\
\text { cities, } 60 \% \text { in greater Jakarta } \\
\text { Local }\end{array}$ & $\begin{array}{l}\text { women } 25-35 \text { focusing to healty lifestlyle } \\
\text { available throughout the country using reseler services } \\
\text { Local and International }\end{array}$ & $\begin{array}{l}\text { urban people } \\
\text { local }\end{array}$ \\
\hline $\begin{array}{l}\text { Strategy } \\
\text { Marketing }\end{array}$ & $\begin{array}{l}\text { increase the volume of } \\
\text { production and export markets } \\
\text {. New ( plans in exports to the } \\
\text { middle east ) } \\
\text { focus on variant of having a } \\
\text { stable sales, a seasional only } \\
3 \text { made per month. }\end{array}$ & $\begin{array}{l}\text { To increase the volume of sales in local and international } \\
\text { markets have exports to america }\end{array}$ & N/A \\
\hline $\begin{array}{l}\text { Distribution } \\
\text { Network }\end{array}$ & $\begin{array}{l}\text { Online channel and store } \\
\text { offline premium }\end{array}$ & $\begin{array}{l}\text { Online channel and modern market, Offer reseler } \\
\text { program at a lower price }\end{array}$ & $\begin{array}{lr}\text { New - in } & \text { e-commers } \\
\text { tokopedia } & \text { and } \\
\text { nutrimart.co.id } & \\
\end{array}$ \\
\hline $\begin{array}{l}\text { Understand } \\
\text { consumers }\end{array}$ & $\begin{array}{l}\text { market study by learning by } \\
\text { doing a variant of trying to see } \\
\text { and the need for food low in } \\
\text { calories }\end{array}$ & $\begin{array}{l}\text { - The process of making products based on R\&D that } \\
\text { puts forward the health aspect especially to meet the } \\
\text { challenges komorbit disease indonesia largest namely } \\
\text { obesity and diabetes }\end{array}$ & N/A \\
\hline $\begin{array}{l}\text { Technology } \\
\text { application }\end{array}$ & $\begin{array}{l}\text { the technologies used to be in } \\
\text { the factories namely in pt } \\
\text { quindofood third party }\end{array}$ & $\begin{array}{l}\text { use of technology special fabrication owned storage and } \\
\text { air to maintain of product is mainly in seasoning }\end{array}$ & $\begin{array}{l}\text { use of technology owned } \\
\text { fabrication modern }\end{array}$ \\
\hline Social Media & $\begin{array}{l}\text { official account ( instagram } \\
27,9 \mathrm{k} \text { with followers and } 653 \text { ) } \\
\text { facebook posts }\end{array}$ & $\begin{array}{l}\text { official account (instagram 18,1k followers } 756 \text { ) } \\
\text { facebook and youtube posts }\end{array}$ & N/A \\
\hline
\end{tabular}

From explaining, above so arranged table CPM for measuring success factors critical of PT. Fit Indonesia Tama (Fitmee), PT Aquasolve Sanaria (Ashitaki), dan PT Nutrifood Indonesia (Tropicana Slim Shirataki Noodles) as company instant noodles made from porang.

The weighting is determined based on how big the influence of parameter success factors the critical to a successful business strategy in achieving its objectives. More weight means parameters had contributed and influence of increasingly large due to the perceived success company.

Table 2 Competitive Profile Matrix - Critical Success Factor

\begin{tabular}{|l|l|l|l|l|l|l|l|l|}
\hline \multirow{2}{*}{ No. } & Critical Success Factor & Type & Fitmee & \multicolumn{2}{l|}{ Ashitaki } & \multicolumn{2}{l|}{ Tropicana Slim } \\
\cline { 3 - 9 } & & & Value & Score & Value & Score & Value & Score \\
\hline 1 & A media campaign to promote & 0.15 & 2 & 0.30 & 3 & 0.45 & 1 & 0,15 \\
\hline 2 & Innovation Process & 0.15 & 3 & 0.45 & 4 & 0.60 & 1 & 0,15 \\
\hline 3 & Market Share & 0.10 & 3 & 0.30 & 4 & 0.40 & 1 & 0,10 \\
\hline 4 & Strategy & 0.10 & 3 & 0.30 & 2 & 0.20 & 1 & 0,10 \\
\hline 5 & Distribution Network & 0.15 & 2 & 0.30 & 3 & 0.45 & 1 & 0,15 \\
\hline 6 & Understand Consumers & 0.15 & 3 & 0.45 & 4 & 0.60 & 1 & 0,15 \\
\hline 7 & Technology Application & 0.10 & 1 & 0.10 & 4 & 0.60 & 3 & 0,30 \\
\hline 8 & Social Media & 0.10 & 2 & 0.20 & 3 & 0.30 & 1 & 0,10 \\
\hline & Total Source Interview of company from web zoom & $\mathbf{1 0}$ \\
\hline
\end{tabular}

It can be seen that PT. Aquasolves Sanaria as to a trade-mark ashitaki superior in almost all success factors. The process of production using technology more modern and distribution network larger than the other two competitors are Fitmee dan Tropicana slim. Refer to the results CPM on the table above, and it can be said at present PT. Aquasolve Sanaria Potentially is the market-leading category of instant noodles basic made porang.

\section{Customer Behaviour}

Based on the results of "Global Consumer Insight Survey 2020", It turns out that how to transform to changes in consumer behavior that are accelerating the trend to rediscover the consumers to buy. The results of this survey have been said that $69 \%$ of global consumers focus more on mental health and welfare. After covid19 pandemics, five increase the Indonesian consumers' expenditure is the product health 
outcomes were improved as many as $77 \%$, increase compared to the $67 \%$ food for the following week, the collection or delivery of food increased as much as $47 \%$, increased $54 \%$ entertainment and media and activities skills, house renovation and estate crops increased as much as $32 \%$.

The survey of consumers found most respondents still eating rice, 95,2 as much as percent and percent of respondents, 48,5 eating noodles 21,6 , sereal consume percent of respondents and percent of respondents 51,5 eating bread. A kind of basic data porang is due to health benefits for mainly because of this product low on calories and low carb. In addition, many consumers still follow the trend of food consumption patterns healthy and also affected product promotion in education through social media.

\section{Value Chain analysis}

The main activity that adds to the product's value is an activity that is directly involved in the creation of the physical, sales, and delivery on the buyer of seller. Program support that adds to the product's value is supporting activities' primary activity in conducting operations to run better, such as infrastructure, plant, and machinery, human resource management, technology development, and procurement of goods and services. This analysis would disclose competitive advantage or gap.

Based on analyzing the value chain was done with 3 , manufacturing instant noodles can be summarised as follows.
1. Discern to factors that PT Fit Indonesia Tama (Fitmee) is the efficiency of the operation in the creation of value, products where PT Fit Indonesia Tama use a third party. In the other hand, this has led to PT Fit Indonesia Tama having a high dependency to other parties. While in the marketing and sale to the consumer, PT Fit Indonesia Tama supports the strongest men in other business centers as a health club or catering healthy food. This makes PT Fit Indonesia Tama can quickly catch the needs and changes in the behavior of consumers.

2. In the analysis value chain PT Aquasolve Sanaria (Ashitaki) overall it is quite strong because PT Aquasolve Sanaria having a strong infrastructure, namely the factory and $R \& D$ Owned own, so that dependence with a third party is relatively small. PT Aquasolve Sanaria even quickly developed several variants of. To meet the needs of customers. In marketing and sales activity, PT Aquasolve Sanaria has even led to retail, offline for the public not only to modern. the premium market for consumers

3. PT Nutrifood Indonesia, in the analysis of a chain value, has strong support in implementing primary and operation activities supporting activities to other healthy food products. Tropicana Slim having a surplus in connection with consumers because the name was known enough.

\section{Transformative Business Model Analysis}

Table 3. Key identifier successful innovation porang manufacturing industry

\begin{tabular}{|c|c|c|c|c|c|c|c|}
\hline \multirow[t]{2}{*}{ Company } & \multicolumn{6}{|c|}{ Keys to Innovation Success } & \multirow[t]{2}{*}{ Score } \\
\hline & $\begin{array}{l}\text { Persona- } \\
\text { lization }\end{array}$ & $\begin{array}{l}\text { Closed } \\
\text { Loop }\end{array}$ & $\begin{array}{l}\text { Asset } \\
\text { Sharing }\end{array}$ & $\begin{array}{l}\text { Usage-Based } \\
\text { Pricing }\end{array}$ & $\begin{array}{l}\text { Collaborative } \\
\text { Ecosystem }\end{array}$ & Agility & \\
\hline Fitco Company (Fitmee) & $\checkmark$ & & & & $\checkmark$ & & 2 \\
\hline $\begin{array}{l}\text { PT Aquasolve Sanaria } \\
\text { (Ashitaki) }\end{array}$ & $\checkmark$ & & & & $\checkmark$ & $\checkmark$ & 3 \\
\hline $\begin{array}{l}\text { PT. Nutrifood Indonesia } \\
\text { (Tripicana Slim Shirataki) }\end{array}$ & & & & & & & \\
\hline
\end{tabular}

The industry's transformation is often associated with the adoption of new technology, but new technology never automatically changes the industry by itself. There is a need for a business model that connects new technology with the 
developing market needs. The identification of six key innovation successes was based on an analysis of 40 new business models. A key innovation to have the potential to change the industry. Model company with higher than six numbers associated with the odds a transformation that higher.

From the table above, the following identification success innovation in the transformative business model for 3 company instant noodles porang based, where a company that owns the highest score is PT Aquasolve Sanaria (Ashitaki), As many as 3 the key to success is as follows.

On products and services more personal, personalize them fitmee in using the technology done through platform sales websites can relate to social media Fitmee like Instagram, Facebook, dan youtube. Website Fitmee can also connect with various business lines from its parent Fit Company, such as FitCo Move and FitGourmet. Fitmee also associates consumers with healthy other products, like soup in the form of sachets, honey, or nuts. At the same time, Ashitaki personalizes them to meet the market needs by making a variant of it that can include broad segments of consumers feel cared for. Thus, like two competitors, Tropicana Slim Mie Shirataki started the test out a product with variant adapted to the peculiar taste of Nusantara fried noodles java special. Three companies see instant noodles based on porang can be concluded that personalization is new there in creating a taste as an approach to consumers in Indonesia.

At process, a closed-loop from Fitmee, Ashitaki, then Tropicana Slim still had no closed-loop process. The process still is open, involves the loop where the produce outputs do not affect the input of a system. While, on asset sharing, the results of interviews and analysis chain value did to three companies producing porang, instant noodles are based from PT. Fit Indonesia Tama, PT. Aquasolve Sanaria, then Tropicana Slim, has not pursued a policy of share assets with other parties to create added value for the company until now. On quotations based on the use of do not base on the use of by consumers. The prices were carried out based on the cost of starting the company production process up to the distribution process product to a market.

In a collaborative of ecosystems, Fitmee has a collaborative ecosystem both in optimizing technology and meeting the needs of the market. There are two indicators in fulfilling market needs: an increase in demand for products and an increase in the costs input (raw materials, transportation, and human resources). Besides, Ashitaki marketing forms its own ecosystem by collaborating and build the base reseller across Indonesia. Collaborative in terms of marketing also be conducted by holding the activities promotion by an event held together with a third party, for example, by a gymnasium Best Fitness, Sales promotion with the modern market as a distribution in offline by making a special product promotion ashitaki. Ashitaki focuses more on-demand rise market to their products. Thus, collaborative ecosystem Tropicana Slim as a newcomer uses a database holding company PT Nutrifood Indonesia.

On how to work nimble and adaptive, Fitmee applies ways of working at the start of its firm foundation of agile, through the proceeds of selling using a cart at first that a flexible can make the sale at once get inputs from the customers. After that, there is no significant and has only been the development of which agile is available continuously in product development and the activities of his supporters. Besides, Ashitaki Applies ways of working agile constantly in an attitude of reform in fulfilling a wide range of market needs. A unit R\&D also supports it Ashitaki is trying to develop their products in new variants. Thus, PT Nutrifood Indonesia Has implemented an overall framework agile and adaptive manner for all products produced. The agility and adaption are not specified in its new products of Shirataki 
Noodles, but they have been operating for a long time ago.

\section{CONCLUSIONS}

The company instant noodles are based on porang, currently growing rapidly; one of the main factors that prompted the COVID-19 pandemic is forced the new habit of Indonesian people to consume more healthy food. Since 2017 first instant noodles are based on porang in Indonesian society. The sales increased by more than $600 \%$ launched the first time (Interview result from PT. Aquasolve Sanaria); competitors with a company have the trend sales rises. At the level of the market's current condition, a monopoly supplier also makes the company dependent in excess. Having no other suppliers, it can be said concerning suppliers or if there is a decision to stop supply cooperate in it to a basic made this porang instant noodles have ascertained company will a covering or need to change their products with the basic made non-porang. This condition can be concluded that the existence of the noodles is based on porang relying on sole supplier.

The company instant noodles made from porang it is just so big to be able to local and international in the category of instant noodles made from porang. The company instant noodles are based porang is a huge market over local as well as international for the instant noodles are based on data porang in Indonesia there were new 167 respondents are 62,9\% know the existence products of porang noodles are based with the level of consumption only 18 $\%$ (Consumer Data Survey). The company instant noodles based porang use of information technology that develops current to educate people, as social media Instagram and Facebook, But the effort was somewhat maximally because its scope was still there tiny. The mainstream media have not been an alternative to socializing this product because of the company instant noodles uranium-based porang considering the high cost to be issued for the socialization. The cost of socialization at mainstream media could not yet be a subsidy from the sale of products instant noodles made from porang that are relatively expensive. However, it has not added promotional costs in it. The global market has the potential to, promised where PT. Aquasolve Sanaria has done exports to America and preparing for opening Market in Europe. Besides, the competitor PT. Fit Indonesia Tama has prepared itself to satisfy a demand out of some countries in the Middle East. This suggests that products produce have adequate export products and get trust both the local markets and international.

\section{Acknowledgement: None}

\section{Conflict of Interest: None}

\section{Source of Funding: None}

\section{REFERENCES}

1. Bhattacharjee, D. and Dey, M. (2015) 'Competitive Profile Matrix: a Theoretical Review', ABAC Journal Assumption University, 35(2), pp. 61-70. Available at: http://www.assumptionjournal.au.edu/index. php/abacjournal/article/view/3022/1942.

2. Cadle, J., Paul, D. and Turner, P. (2010) Business Analysis Techniques - 72 Essential Tools for Success, Aluminium Today. British Informatics Society Limited (BISL). doi: 10.1016/b978-0-7506-0683-7.50010-x.

3. Engel, J. F., Blackwell, R. D. and Miniard, P. W. (2001) 'Perilaku Konsumen, Jilid 2', Jakarta: Binarupa Aksara.

4. Gorissen, L., Vrancken, K. and Manshoven, S. (2016) 'Transition thinking and business model innovation-towards a transformative business model and new role for the reuse centers of Limburg, Belgium', Sustainability (Switzerland), 8(2). doi: 10.3390/su8020112.

5. Kavadias, S., Ladas, K. and Loch, C. (2016) 'The transformative business model', Harvard Business Review, 2016(October).

6. Norman M. Scarborough and Cornwall, J. R. (2016) Essentials of Entrepreneurship and Small Business Management, Global Edition, Upper Saddle River. 
Novrizal et.al. The increase in porang instant noodle market share from the perspective of transformative business model analysis.

7. Ovidijus Jurevicius (2013) Competitive Profile Matrix (CPM) | SMI, Strategic Management Insight.

8. Schiffman, L. G., Kanuk, L. L. and Hansen, H. (2012) Consumer Behaviour: A European Outlook, Pearson Education.

9. Wheelen, T. E. et al. (2018) Strategic Management and Business Policy Fifteenth Edition. fifteenth, Pearson Education. I. fifteenth. Edited by N. Bhalla. Pearson Education Limited. Available at: https://testbank24.com/pdf/SolutionsManual-Strategic-Management-andBusiness-Policy-Globalization-Innovation-
and-Sustainability-14th-Edition-

Wheelen.pdf.

10. Pearce Robinson, Manajemen Stratejik Formulasi, Implementasi dan Pengendalian Jilid 1, Binarupa Aksara, 1997, 231.

How to cite this article: Novrizal, Rahayu F, Phangestu $\mathrm{J}$ et.al. The increase in porang instant noodle market share from the perspective of transformative business model analysis. International Journal of Research and Review. 2021; 8(6): 117-126. DOI: https://doi.org/10. 52403/ijrr.20210614 